\title{
DETERMINANTS OF AUDIT REPORT LAG: EFFECT OF CORPORATE GOVERNANCE IN LISTED COMPANIES IN THE MALAYSIAN CONSTRUCTION INDUSTRY
}

\author{
Syahmi Akmal bin Kusin ${ }^{1}$ and Mohd Halim bin Kadri ${ }^{2}$ \\ 'E-mail: syahmiakmalkusin@gmail.com \\ ${ }^{2}$ Universiti Teknologi MARA, Malaysia \\ E-mail:mhalim@uitm.edu.my
}

\begin{abstract}
Timeliness of audited financial reports is pondered to be a crucial and important factor affecting the usefulness and quality of information that is available to its users. This study examined the effect of corporate governance on audit report lag in listed companies in the Malaysian construction industry. The construction industry in Malaysia is one of the most challenging and dynamic. The Agency Theory is a relevant theory to this study as it explains corporate governance which functions as an oversight mechanism to lessen agency problems. This study particularly examined the effect of board size, board diversity, board meeting, CEO duality, audit committee size and type of auditor on audit report lag. The study collected data covering a three-year period from 2015 to 2017. The study sample comprised of 138 Malaysian listed companies in the sector from Bursa Malaysia. Data were extracted from the annual report of the sample companies that was downloaded from the Bursa Malaysia website. Regression analysis was performed to examine the relationship between corporate governance attributes and audit report lag. The results demonstrated that board size, board diversity and auditor type have a significant relationship with audit report lag. Meanwhile, board meeting, CEO duality and audit committee size do not have a significant relationship with audit report lag. This study contributes to the literature on corporate governance and auditing. Particular explanations of the findings, implications, limitation and recommendation for future research are highlighted.
\end{abstract}

Keywords: Audit report lag, corporate governance, construction companies, Malaysia

ARTICLE INFO

Article History:

Received: 29 April 2020

Accepted: 26 September 2020

Published: 31 December 2020 


\section{INTRODUCTION}

The purpose of financial reporting is to provide users with quality information that could help in their decision-making process. Users of financial information usually demand for complete, transparent and timely information; therefore, the financial information should be of higher quality before it is delivered to them (Shukeri \& Islam, 2012). Further, the usefulness of accounting information will depend on the completeness, accuracy, reliability and timeliness (Hassan, 2016). This shows that timely financial reporting is considered as one of the qualities of financial reporting that leads to effective decision making. It is also supported by professional accountants, auditors and other regulators, that timeliness financial reporting is an important characteristic of financial reporting quality (Ahmed \& CheAhmad, 2016; Sakka \& Jarboui, 2016). As defined by the US Financial Accounting Standard Board (FASB) and the International Accounting Standards Board (IASB), timeliness is the information provided to the decision maker before the capacity to influence the decision is loss (Puasa, Salleh, \& Ahmad, 2014). In addition, it portrays the readiness of companies to deliver information and announce their earning to stakeholders. Timeliness financial reporting is perceived as a way of reducing information asymmetry (Sakka \& Jarboui, 2016). Hence, it will help to diminish insider trading, leaks, rumours that may affect a companies' financial health and performance (Al Daoud, Ku Ismail, \& Lode, 2015; Hassan, 2016). Furthermore, all companies should strive to reduce their audit report lag in order to improve the market efficiency of the company (Mahmoud Ezat, 2015).

The Malaysian government has boosted corporate governance by refining the guidelines and principles required on firms regardless of their categories (Alnasser, 2012). The Malaysian Code on Corporate Governance (MCCG) 2017, defined corporate governance as the procedure and structure used to steer and manage the business and affairs of the company towards encouraging business success and corporate accountability with the ultimate objectives of long-term shareholder value while considering the interest of other stakeholders. Notably, corporate governance provides a framework for a control mechanism that helps the company in fulfil its goals, while preventing undesirable conflicts (Al Daoud et al., 2015; Azubike \& Aggreh, 2014). Further, corporate governance is not only concerned with shareholder interest but as well as other stakeholders. It is commonly accepted that 
audit report lag is associated with corporate governance variables such as board size, board diversity, board meeting, chief executive officer duality, audit committee size and auditor type (Al Daoud, Ku Ismail, \& Lode, 2014; Ilaboya \& Christian, 2014; Puasa et al., 2014; Shukeri \& Islam, 2012). The Agency Theory proposes that corporate governance has the direct obligation in promoting financial reporting quality and oversight processes which affect audit report lag. Hence, effective corporate governance should lessen business risks and enhance internal controls to shorten audit report lag.

The Malaysian Anti-Corruption Commission (MACC) has reported that the construction industry has been identified as a high-risk industry exposed to high levels of corruption compared to other industries. Accordingly, the construction industry in Malaysia is one of the most challenging and dynamic industry (Abdul Rahman, Wang, \& Sheik Mohamad, 2015). Studies show that risk and uncertainty have continuously troubled the construction industry compared to other industries due to its complexity of business activities, processes, environment, organization and time-consuming characteristics (Abdul Rahman et al., 2015; Siang \& Ali, 2012; Mhetre, Konnur, \& Landage, 2016). Due to that, users of financial reporting of construction companies need timely information for making effective decisions. Even though several attempts have been made to study the determinants of audit report lag which include firm characteristics and corporate governance characteristics (Abernathy, Barnes, Stefaniak, \& Weisbarth, 2016; Agyei-Mensah, 2018; Alsmady, 2018; Gamayuni, Karlina, \& Lindrianasari, 2018; Habib \& Bhuiyan, 2011; Lirungan \& Harindahyani, 2018; Rusmin \& Evans, 2017; Salehi, Bayaz, \& Naemi, 2018; Salleh, Baatwah, \& Ahmad, 2017), none of it specifically look at the construction industry.

An audited financial statement is the most reliable source and reference of accounting information to external users. In developing countries, the importance of timely financial reporting is more widespread than other countries because financial reports are the only reliable source of information available to external users (Basuony, Mohamed, Hussain, \& Marie, 2016). However, the time taken by external auditors to complete their audit work will likely have effect on the timeliness of financial reporting (Ilaboya \& Christian, 2014). A long time taken by the external auditor to complete the audit work will make the financial information less valuable for users. 
Auditing is a time-consuming activity, thus the auditor needs to have proper audit planning to reduce the time taken in completing the audit work (Ilaboya $\&$ Christian, 2014). The collapse of high-profile corporate organisations and everlasting scandals in the corporate world have pulled so much attention and enlarged the debate on the effectiveness of corporate governance as a medium of reducing audit delay (Ilaboya \& Christian, 2014).

The issue of timely financial reporting has been increasingly addressed by accounting standards setting entities all over the globe because the delay of financial reporting is most likely to boost information asymmetry and uncertainty in investment decisions (Mohamad-Nor, Shafie, \& WanHussin, 2010). The United State Securities and Exchange Commission (SEC), the New York Stock Exchange (NYSE) and National Association of Securities Dealers Automated Quotations (NASDAQ) have all established requirements and recommendations regarding the timeliness of issued financial reporting (Al Daoud et al., 2014). In Malaysia, the provision in Chapter 9 of the Bursa listing requirements, requires all listed companies to produce timely financial reporting and submit their audited financial statement within a period not exceeding 4 months from the financial yearend (Bursa Malaysia, 2015; Wan Hussin, Bamahros, \& Shukeri, 2018). The current scenario in Malaysia shows the inability of companies in submitting their audited annual report according to the timeframe proposed by Bursa Malaysia (Hashim, 2017). Due to that, the issue of delay in issuing audited annual reports is viewed as a serious matter by Bursa Malaysia. Bursa Malaysia together with the Securities Commission have taken steps to prevent companies from late submission of their audited annual report. A penalty will be imposed to public listed companies for failure to disclose within the timeframe (Hashim, 2017). Despite that, there are still few companies that could not meet the submission deadline and being imposed a penalty due to breach of listing requirements by Bursa.

Although there are several studies that have documented audit report lag in Malaysia (Ahmed \& Che-Ahmad, 2016; Apadore \& Noor, 2013; Hashim, 2017; Hashim \& Abdul Rahman, 2011; Mohamad-Nor et al., 2010; Nelson \& Shukeri, 2011; Puasa et al., 2014; Salleh et al., 2017; Shukeri \& Islam, 2012), studies examining the effect of new listing requirements by Bursa starting from 2016 in relation to corporate governance elements and audit report lag is still inadequate. Companies with a financial year ending 
on or after $31^{\text {st }}$ December 2014 need to publish their annual report to Bursa within 5 months from the close of the financial year. Subsequently, from 2016, public listed companies are required to publish their annual report for financial year ending on or after $31^{\text {st }}$ December 2015 within 4 months from the close of the financial year (Malaysian Accounting Standard Board, 2015). The amendment was made accordingly to enhance the timeliness of publication of the annual report so as to be able to align with other markets (Salleh et al., 2017; The Sun Daily, 2013). Nevertheless, the timeframe for public listed companies in Malaysia to submit their annual report is still relatively longer compared to other markets, such as the US market which requires their companies to submit the audited annual report within 2 months (Abernathy et al., 2016).

In the light of the importance of financial reporting timeliness, detecting the determinants of audit report delay is viewed as a significant step to improve the quality of reporting. Therefore, the purpose of this study was to examine the association between corporate governance and audit report lag in listed companies in the construction industry in Malaysia from 2015 to 2017

\section{LITERATURE REVIEW AND HYPOTHESIS DEVELOPMENT}

In identifying the relationship between owners and managers, the Agency Theory has been the one of the most important theories (Bouckova, 2015). The distinction of ownership and control in firms, may result in conflicts of interest between owners and managers (Dawar, 2014). Jensen and Meckling (1976) indicate that agency problems occur due to the inability of owners to directly monitor the agents. Therefore, owners demands the financial report to be certified by a professional and independent accounting expert to reduce agency problems (Akingunola, Soyemi, \& Okunuga, 2018). Good corporate governance is seen as a great tool or mechanism for an efficient control of companies, enhancing the performance of the companies and for a better approach for external financing (Boshkoska, 2014). Corporate governance will play its role in monitoring overall performance of the company which include guaranteeing quality of the financial reports as well as timeliness of audited financial statements (Hashim, 2017; Shukeri \& Islam, 2012). The 
Agency Theory is a relevant theory to this study as it explains that corporate governance functions as an oversight mechanism to lessen agency problems (Apadore \& Noor, 2013; Hassan, 2016).

In some previous studies, audit report lag is described as audit delay which represents the number of days elapsing between the date of the financial year end to the auditor report date (Afify, 2009; Ahmed \& CheAhmad, 2016; Azubike \& Aggreh, 2014; Basuony et al., 2016). A number of studies have identified and discovered that audit report lag is influenced by corporate governance such as board size, board duality, board diversity, frequency of meetings, audit committee, external auditor and so on, (Abernathy, Beyer, Masli, \& Stefaniak, 2014; Afify, 2009; Baatwah, Salleh, \& Ahmad, 2015; Habib, 2013; Ilaboya \& Christian, 2014; Pizzini, Lin, \& Ziegenfuss, 2012). Overall, several studies in Malaysia have documented that on average, Malaysian companies take approximately 100 to 116 days to publish their annual reports (Mohamad-Nor et al., 2010; Nelson \& Shukeri, 2011; Puasa et al., 2014).

\section{Board Size}

When determining board size, it is always argued whether a smaller or larger board is more effective. The Board of directors is an important mechanism in corporate governance because it holds the top position in an organisation. The Board plays a vital function in monitoring and in taking strategic decisions, thus the number of directors on the company's board is important (Ezat \& El-masry, 2007). Al Daoud et al. (2015) have shown a significant relationship between board size and timeliness of financial reporting. The study found that large board had increased audit report lag in Jordanian listed companies. Hassan (2016) reported a significant relationship between board size and timely financial reporting in Palestenian listed companies. The study reported that a large board size reduced audit report lag. Ahmed and Che-Ahmad (2016) demonstrated a significant relationship between board size and audit report lag. The study reported that large board size reduces audit report lag in Nigerian listed companies.

In contrast, Ilaboya and Christian (2014) reported no significant relationship between board size and audit report lag in Nigerian listed companies. Further, larger boards size was found to increase audit report lag in the study. 
$\mathbf{H}_{\mathbf{1}}$ : There is a significant relationship between audit report lag and board size.

\section{Board Diversity}

The existence of females in the board of directors has shown a positive influence on reducing conflict among board members. Further, it has been suggested from previous studies that gender diversity will have behavioural effects, which lead to better outcomes of a company's performance and could affect audit report lag (Ahmed \& Che-Ahmad, 2016; Khuong, Thi, \& Vy, 2017). A previous study in Nigeria conducted by Ahmed and Che-Ahmad (2016) showed significant relationship between board diversity and audit report lag. The result reported that an increase in female board members contributed to shorten audit report lag. Another previous study conducted by Khuong et al. (2017) reported a significant relationship between board diversity and audit report lag in Vietnamese listed companies. The increase of females in the board of directors reduced audit report lag in their sample. A recent study in Jordan conducted by Alsmady (2018) shows a significant relationship between board diversity and audit report lag. However, the study documented that existence of women in the board of directors does not help to shorten audit report lag.

In contrast, a previous study by Singh and Sultana (2011) reported no significant relationship between board diversity and audit report lag in Australian listed companies. However, the study showed that the existence of women in the board of directors reduced audit report lag in their sample.

$\mathbf{H}_{2}$ : There is a significant relationship between audit report lag and board diversity.

\section{Board Meeting}

The level of activities of a board can be evaluated through the frequency of meetings (Appah \& Emeh, 2013). Activities of the board would reflect the board's engagement in performing their role as an agent representing the shareholders in the company (Hashim \& Abdul Rahman, 2010). The objective of board meetings is to encourage all directors to share their views and discuss issues relevant to the company such as management 
and organizational performance (Al Daoud et al., 2015). This will help the company to sustain and improve their performance. It has been shown that an effective board of directors is linked with more frequent board meetings as it helps the board to enhance monitoring activities over the process of financial reporting (Greco, 2011). A previous study conducted by Al Daoud et al. (2015) in Jordanian firms reported a significant relationship between board meetings and audit report lag. The study indicated that more frequent board meetings would reduce audit report lag which enhances timely financial reports. Similar to a previous study conducted by Ahmed and CheAhmad (2016) who found a significant relationship between board meeting and audit report lag in Nigerian listed companies. The study indicated that increase in the frequency of board meetings would reduce audit report lag. A recent study conducted by Bakare, Taofiq, and Jimoh, (2018) in Nigerian insurance firms reported a significant relationship between board meeting and audit report lag. The study found that an increase in board meeting frequency increased audit report lag.

On the other hand, a previous study by Singh and Sultana (2011) shows no significant relationship between board meeting and audit report lag in Australian listed companies. The results indicate that an increase in board meetings would prolong audit report lag.

$\mathbf{H}_{3}$ : There is a significant relationship between audit report lag and board meeting.

\section{Chief Executive Officer Duality}

Chief executive officer duality commonly exists when the same person holds the position of chairman of the board and also the CEO for the company (Mohamad-Nor et al., 2010). This situation, will impair board independence and also act as an oversight function as a board of directors (Abdullah, 2006). High concentration of power is likely to compromise the board's independence and also have a negative impact on shareholder's wealth when combining both of these roles (Sakka \& Jarboui, 2016). The separation between chairman and CEO position should provide better encouragement to the chairman to act in the interest of the shareholder rather than to preserve the interest of the CEO. A previous study conducted by Afify (2009) shows a significant relationship between CEO duality and audit 
report lag. The study demonstrated that separating the roles of chairman and CEO increases the effectiveness of internal controls, thus it shortens audit report lag. A previous study conducted by Al Daoud et al. (2015) reported a significant relationship between CEO duality and audit report lag in Jordanian listed companies. The study showed that the separated roles of the chairman of board and CEO shortened audit report lag. Similar to a previous study conducted by Alfraih (2016) which showed a significant relationship between CEO duality and audit report lag on Kuwaiti listed companies.

However, a previous study conducted by Hassan (2016) in Palestine found no significant relationship between CEO duality and audit report lag. The result from this study indicates that the separation of roles of the chairman and the CEO is more likely to have a longer audit report lag. Separating the roles of the chairman and the CEO will reduce the risk of audit failure; hence an extensive audit will be conducted to ensure the quality of the audit.

$\mathbf{H}_{4}$ : There is a significant relationship between audit report lag and chief executive officer duality.

\section{Audit Committee Size}

An audit committee will monitor financial reporting practices and respond to the emergence of problems in the company. In addition, effective audit committees in terms of size will enhance internal controls in the company and the time taken by the external auditors to complete their audit work could be reduced (Lirungan \& Harindahyani, 2018). The functions of audit committees are unexpected to be effective if they are too small or too large (Alqatamin, 2018). An adequate number of audit committee members would enable the committee to use the experiences and expertise in the best interest of stakeholders. A previous study conducted by Mohamad-Nor et al. (2010) showed a significant relationship between audit committee size and audit report lag in Malaysian listed companies. A larger audit committee size tends to have a good quality financial reporting in terms of audit timeliness. Thus, this will help to reduce audit report lag. A previous study conducted by Nelson and Shukeri (2011) found a significant relationship between audit committee size and audit report lag in Malaysian listed companies. 
The result reported that a large audit committee tends to strengthen the internal controls of the company. Thus, it will reduce audit report lag. This is similar to a recent study conducted by Lirungan and Harindahyani (2018) who reported a significant relationship between audit committee size and audit report lag in Indonesian listed companies.

In contrast, a previous study conducted by Cunha, Pletsch, and Silva (2016) reported no significant relationship between audit committee size and audit report lag in Brazilian listed companies. However, the study found that an increase in audit committee members would reduce audit report lag.

$\mathbf{H}_{5}$ : There is a significant relationship between audit report lag and audit committee size.

\section{Auditor Type}

Auditor type refers to the type of firm that audits the financial reports of the company. The expectation is that the audit lag for larger audit firms will be less than smaller audit firms. Large audit firms usually associate with higher audit quality due to the resources and technologies (Nelson \& Shukeri, 2011). The Big Four audit firms have better experienced staff and well-programmed audit procedures to enhance their effectiveness in performing audit processes compared to small audit firms (Hassan, 2016; Lee \& Jahng, 2008). Since the loss of reputation from poor audit services has become the main concern for large audit firms, they have to complete their audit work on time and provide high quality audits (Hassan, 2016). Meanwhile, small audit firms are more likely to depend on their clients' fees for their business survival and may be contend to avoid audit lag because a listed company is important to them (Badawy \& Aa, 2018). A previous study conducted by Shukeri and Islam (2012), reported a significant relationship between auditor type and audit report lag in Malaysian listed companies. The study agrees that large audit firms are more likely to complete their audit work on time compared to small audit firms. A previous study conducted by Cunha et al. (2016) demonstrated a significant relationship between auditor type and audit report lag in Brazilian listed companies. The result from the study showed that companies audited by the Big Four are prone to produce timely reports compared to companies audited by the non-Big Four. Similar to a recent study conducted by Lirungan and Harindahyani (2018) who found a significant relationship between auditor type and audit report 
lag in Indonesian listed companies. The study indicated that the companies audited by the Big Four are able to provide timely financial reporting.

However, a previous study conducted by Afify (2009) showed no significant relationship between auditor type and audit report lag Egyptian listed companies. The result from the study also indicated that companies audited by the Big Four will prolong audit report lag.

$\mathbf{H}_{6}$ : There is a significant relationship between audit report lag and auditor type.

\section{RESEARCH METHODOLOGY}

This study applied a quantitative methodology since corporate governance characteristics and audit report lag can be evaluated into numerical form (Queirós, Faria, \& Almeida, 2017). Secondary data were retrieved from Public Listed Company annual reports at Bursa Malaysia from 2015 to 2017.

\section{Data and Sample Selection}

This study focused on construction companies listed on the main market of Bursa Malaysian. There were 147 companies listed under the construction industry as at $31^{\text {st }}$ August 2018. The sample was selected based on the companies listed over a three-year period from year 2015 to 2017. However, after removing companies with unattainable information, only 138 companies were useable for this study. Thus, the sample size selected in this study was 138 companies from the construction industry and represented $94 \%$ of construction companies in the industry. There were 138 observations over the three-year period from 2015 to 2017 . This number of observations was used as empirical evidence in this study. Table 1 provides the summary of the final sample in this study.

The information relating to the date of the audit report signed, board size, board diversity, board meeting, chief executive officer duality, audit committee size and auditor type was collected manually from the annual reports of the companies from 2015 to 2017. All the audited annual reports were downloaded from the Bursa Malaysia website. 
Table 1: Sample Selection

\begin{tabular}{lc}
\hline Construction companies listed in the main board of Bursa & No of Companies \\
Malaysia & 147 \\
Less: & \\
$\quad$ Companies with missing audit report date & 9 \\
\hline Final Sample Size & 138 \\
\hline
\end{tabular}

\section{Variable and Measurement}

The details of measurement of all seven operational variables used in examining the research objectives are presented in Table 2 below. This is consistent with previous literature that used corporate governance as an independent variable as they have been found to be associated with audit report lag (Afify, 2009; Ahmed \& Che-Ahmad, 2016; Mohamad-Nor et al., 2010; Nelson \& Shukeri, 2011; Shukeri \& Islam, 2012).

The measurement of the dependent and independent variables are usually used in the most recent audit report lag and corporate governance literature. In measuring audit report lag, this study used the number of days that elapsed between the day of the financial year end to the auditor report date. This is similar to a previous study conducted by Hashim (2017) which measured audit report lag using the number of days that elapsed between the day of the financial year end to the auditor report date. As required by Bursa Malaysia, companies need to submit their annual report to the Bursa within 4 months. Thus, by using this measure it can indicate the time required by companies to submit their annual report to Bursa.

As for board size, this study measured by using the total number of directors on the board and it is also in line with a previous study conducted by Salehi et al. (2018) that also measured board size using the total number of directors on the board. The Bursa Malaysia Corporate Governance guide stated there is no specific number of directors who should be on the board of directors, however the board of directors plays a vital role in monitoring and in taking strategic decisions. This study measured board diversity using the number of females in the board of directors. This was adopted from a previous study conducted by Ahmed and Che-Ahmad (2016) that measured board diversity using the number of females in board of directors. As proposed by The Malaysian Code on Corporate Governance, companies 
must have gender diversity in the board of directors. Further, gender diversity will have a behavioural effect that improves the effectiveness of oversight function (Ahmed \& Che-Ahmad, 2016). In measuring board meetings, this study used the number of board meetings held during the financial year. This is similar to a previous study conducted by Bakare et al. (2018) that measured board meeting by using the number of board meetings held during the financial year. According to the Corporate Governance Guide by Bursa Malaysia, the board should meet regularly or at least once every quarter to carry out an effective role and responsibilities as a monitoring mechanism. This study measured chief executive officer (CEO) duality by identify if the position of CEO and chairman is held by the same person or were separated. It is coded as " 0 " if the positions of CEO and Chairman were separated and "1" if otherwise (Salehi et al., 2018). The Malaysian Code on Corporate Governance also recommends companies to have two different individuals who hold the chairman of the board and CEO position so as to ensure a proper monitoring function by the top management. As for audit committee size, this study measured it by using the total number of directors on the audit committee (Salehi et al., 2018). This is adopted from a previous study conducted by Salehi et al. (2018) that measured audit committee size using the total number of directors on the audit committee. The establishment of an audit committee is compulsory as stated in the Bursa Malaysia listing requirement. Further, it is required that there are at least 3 members in the audit committee and at least one of them must have financial expertise. In measuring auditor type, this study identified if the external auditor for the companies were from the Big Four accounting firms or non-Big Four. It was coded as " 0 " if the external auditor was from the non-Big Four and "1" if otherwise (Lirungan \& Harindahyani, 2018). 
Table 2: Operationalization of Model Variables

\begin{tabular}{|c|c|c|}
\hline Variables & Measurement & Author \\
\hline $\begin{array}{l}\text { Dependent: } \\
\text { Audit report lag } \\
(A R L)\end{array}$ & $\begin{array}{l}\text { The number of days elapsing } \\
\text { between the date of financial year } \\
\text { end to the auditor report date }\end{array}$ & $\begin{array}{l}\text { Hashim (2017); Nelson } \\
\text { \& Shukeri (2011); Wan } \\
\text { Hussin et al. (2018); Salehi } \\
\text { et al. (2018) }\end{array}$ \\
\hline $\begin{array}{l}\text { Independent: } \\
\text { Board size } \\
\text { (BSIZE) }\end{array}$ & $\begin{array}{l}\text { The total number of directors on } \\
\text { the board }\end{array}$ & $\begin{array}{l}\text { Salehi et al (2018); Alfraih } \\
\text { (2016); Fakhfakh et al. } \\
(2016) ; \text { Hassan (2016) }\end{array}$ \\
\hline $\begin{array}{l}\text { Board diversity } \\
\text { (BDIVER) }\end{array}$ & $\begin{array}{l}\text { The number of female directors in } \\
\text { board of directors }\end{array}$ & $\begin{array}{l}\text { Singh \& Sultana (2011); } \\
\text { Ahmed \& Che-Ahmad } \\
\text { (2016); Alsmady (2018) }\end{array}$ \\
\hline $\begin{array}{l}\text { Board meeting } \\
\text { (BMEET) }\end{array}$ & $\begin{array}{l}\text { The number of board meeting held } \\
\text { during the financial year }\end{array}$ & $\begin{array}{l}\text { Hashim \& Abdul Rahman } \\
\text { (2010); Al Daoud et al. } \\
(2015) \text {; Bakare et al. } \\
(2018) \text {; Hassan et al. } \\
(2015)\end{array}$ \\
\hline $\begin{array}{l}\text { Chief executive } \\
\text { officer duality } \\
\text { (CEODUAL) }\end{array}$ & $\begin{array}{l}\text { It is coded as "0" if positions of CEO } \\
\text { and chairman were separated and } \\
\text { "1" if otherwise }\end{array}$ & $\begin{array}{l}\text { Salehi, et al. (2018); Al } \\
\text { Daoud et al. (2015); Alfraih } \\
\text { (2016); Hassan (2016) }\end{array}$ \\
\hline $\begin{array}{l}\text { Audit committee } \\
\text { size (ACSIZE) }\end{array}$ & $\begin{array}{l}\text { The total number of directors on } \\
\text { the audit committee }\end{array}$ & $\begin{array}{l}\text { Salehi et al. (2018); Cunha } \\
\text { et al. (2016); Oussii \& } \\
\text { Taktak (2018) }\end{array}$ \\
\hline $\begin{array}{l}\text { Auditor type } \\
\text { (AUDTYP) }\end{array}$ & $\begin{array}{l}\text { It is coded as "0" if the external } \\
\text { auditor is non-Big Four " } 1 \text { " if } \\
\text { otherwise }\end{array}$ & $\begin{array}{l}\text { Hashim \& Abdul Rahman } \\
\text { (2010); Cunha et al. (2016); } \\
\text { Lirungan \& Harindahyani } \\
\text { (2018); Sultana et al. } \\
(2015)\end{array}$ \\
\hline
\end{tabular}

\section{Research Model}

The regression equation below was employed for this study to examine the connection between the dependent variable, audit report lag (ARL) and the independent variables, board size (BSIZE), board diversity (BDIVER), board meeting (BMEET), chief executive officer duality (CEODUAL), audit committee size (ACSIZE) and auditor type (AUDTYP). Table 3 shows the summary description of the regression equation model.

$$
\begin{aligned}
& \mathrm{ARL}=\beta_{0}+\beta_{1} \mathrm{BSIZE}+\beta_{2} \mathrm{BDIVER}+\beta_{3} \mathrm{BMEET}+\beta_{4} \mathrm{CEODUAL}+ \\
& \beta_{5} \mathrm{ACSIZE}+\beta_{6} \mathrm{AUDTYP}+\varepsilon
\end{aligned}
$$


Table 3: Description of Regression Equation Model

\begin{tabular}{llc}
\multicolumn{1}{c}{ Symbol } & \multicolumn{1}{c}{ Description } & Relevant Hypothesis \\
\hline$\beta_{0}$ & Estimated intercept & - \\
$\beta_{1}, \beta_{5}$ & $\begin{array}{l}\text { Slope of independent variables } \\
\text { Random error }\end{array}$ & - \\
$\varepsilon$ & Audit report lag & - \\
\hline Dependent variable & & - \\
ARL & Board size & $\mathrm{H}_{1}$ \\
\hline Independent variables & Board diversity & $\mathrm{H}_{2}$ \\
BSIZE & Board meeting & $\mathrm{H}_{3}$ \\
BDIVER & Chief executive officer duality & $\mathrm{H}_{4}$ \\
BMEET & Audit committee size & $\mathrm{H}_{5}$ \\
CEODUAL & Auditor type & $\mathrm{H}_{6}$ \\
ACSIZE & & \\
AUDTYPE & & \\
\hline
\end{tabular}

\section{RESULT AND DISCUSSION}

\section{Descriptive Analysis}

Table 4 provides the descriptive statistics of audit report lag by month for year 2015 to 2017. Five groups are categorised; (i) less than 30 days, (ii) 31 to 60 days, (iii) 61 to 90 days, (iv) 91 to 120 days and (v) more than 120 days.

Table 4: Descriptive Statistics of Audit Report Lag

\begin{tabular}{|c|c|c|c|c|c|c|}
\hline ARL & $\begin{array}{c}\text { No of } \\
\text { companies }\end{array}$ & & $\begin{array}{c}\text { No of } \\
\text { companies }\end{array}$ & & $\begin{array}{c}\text { No of } \\
\text { companies }\end{array}$ & \\
\hline & 2015 & Percent & 2016 & Percent & 2017 & Percent \\
\hline $\begin{array}{l}\text { Less than } 30 \\
\text { days }\end{array}$ & 0 & 0.00 & 0 & 0.00 & 0 & 0.00 \\
\hline 31 to 60 days & 1 & 2.17 & 1 & 2.17 & 1 & 2.17 \\
\hline 61 to 90 days & 10 & 21.74 & 14 & 30.43 & 12 & 26.09 \\
\hline 91 to 120 days & 34 & 73.91 & 31 & 67.39 & 33 & 71.74 \\
\hline $\begin{array}{l}\text { More than } 120 \\
\text { days }\end{array}$ & 1 & 2.17 & 0 & 0.00 & 0 & 0.00 \\
\hline Total & 46 & 100 & 46 & 100 & 46 & 100 \\
\hline
\end{tabular}

Table 5 provides the descriptive statistics of all variables investigated in this study. As shown in Table 5 below, the mean score of ARL for the pooled sample is 99.25 days which is equivalent to 99 days with maximum 
and minimum days of 121 and 55 respectively. This indicated that on average, the companies take about 99 days or 3 months and 3 days to publish their audit report after the financial year end. Thus, the results demonstrate that the companies complied with the Bursa Malaysia listing requirements which required all companies to publish their annual reports within 4 months after the financial year end. However, it was found one company that was unable to submit the annual reports within the 4 month period as shown in Table 4. The result of audit report lag in this study is shorter than the results reported in previous studies by Mohamad-Nor et al. (2010); Nelson and Shukeri (2011); Puasa et al. (2014) which were 100 days, 101 days and 116 days respectively. This could be due to the new listing requirement imposed by Bursa Malaysia where the timeframe for issuance of annual reports has been shortened starting from 2016. This new regulation will affect companies that have a financial year end on or after 30 December 2015. Thus, this could be the explanation for shorter audit report lag in this study and it indicated that the listed companies did not have a problem to comply with the new listing requirement.

The descriptive statistics for corporate governance in Table 5 shows a mean score for board size (BSIZE) as 7.43 which is equivalent to 8 people with a maximum 13 and a minimum 4 . This indicates that on average, the board in these companies consisted of 7 people. Further, the statistics show a mean score of board diversity (BDIVER) as 0.75 which is equivalent to one person with a maximum and minimum number of persons 3 to 0 . This indicates that on average, the companies consisted of at least one female director in the board of directors. The results from the descriptive statistics show that the mean score for board meeting (BMEET) is 5.67 which is equivalent to 6 times with a maximum and minimum of meeting 15 and 3 times respectively. This indicates that the average number of boards meeting held is 6 times. In terms of CEO duality (CEODUAL), the dummy variables when coded 0 indicated the separation of CEO and chairman of the board and when coded 1 indicated that CEO and chairman of the board is held by the same person. The mean score of 0.24 indicated that $24 \%$ of our sample companies combined the roles of CEO and chairman of the board. While the remaining $76 \%$ indicated a separation of the CEO and chairman of the board roles. The results from the descriptive statistics show that the mean score for audit committee size (ACSIZE) is 3.22 which is equivalent to 3 people with a maximum and minimum of members 6 and 2 respectively. 
On average, the number of audit committee members for the companies was 3. Lastly for auditor type (AUDTYP), the dummy variables when coded 0 indicated that the external auditor for the company was a non-Big Four firm and when coded 1 indicated that the external auditor of the company was a Big Four firm. The mean score was 0.33 which indicated that $33 \%$ of the companies were audited by Big Four firms. While, the remaining $67 \%$ were audited by non-Big Four firms.

Table 5: Descriptive Statistics

\begin{tabular}{lcccc}
\multicolumn{1}{c}{ Variables } & Minimum & Maximum & Mean & Standard deviation \\
\hline $\mathrm{N}=138$ & & & & \\
$\mathrm{ARL}$ & 55 & 121 & 99.25 & 12.720 \\
BSIZE & 4 & 13 & 7.43 & 1.956 \\
BDIVER & 0 & 3 & 0.75 & 0.835 \\
BMEET & 3 & 15 & 5.67 & 1.761 \\
CEODUAL & 0 & 1 & 0.24 & 0.428 \\
ACSIZE & 2 & 6 & 3.22 & 0.563 \\
AUDTYP & 0 & 1 & 0.33 & 0.473 \\
\hline
\end{tabular}

Note: Audit Report Lag (ARL), Board Size (BSIZE), Board Diversity (BDIVER), Board Meeting (BMEET), Chief Executive Officer Duality (CEODUAL), Audit Committee Size (ACSIZE), Auditor Type (AUDTYP).

\section{Correlation Analysis}

Correlation analysis is used to find out whether a relationship exists and to determine its magnitude and direction. The Pearson correlation coefficient is referred to as a dimensionless measure that determines the strength of linear relations between two variables (Sari et al., 2017). Table 6 demonstrate the correlation analysis result between all the variables used in this study.

As observed, there was no correlation values higher than 0.9 to indicate that the variables are very high correlated. Remarkably, the correlation between BSIZE and ACSIZE had the highest value compared to other variables. The value of $r=-0.775$ showed a high negative correlation between these variables. Considering the absence of very high correlated variables, these results should not have issues in multicollinearity that would compromise the multiple regression results. 
Table 6: Correlation Analysis of Dependent and Independent Variables

\begin{tabular}{lccccccc} 
& ARL & BSIZE & BDIVER & BMEET & CEODUAL & ACSIZE & AUDTYP \\
\hline ARL & 1 & $-0.181^{*}$ & 0.099 & 0.011 & 0.138 & 0.098 & $-0.248^{* *}$ \\
BSIZE & & 1 & $0.356^{* *}$ & $-0.254^{* *}$ & $0.276^{* *}$ & $-0.775^{* *}$ & $0.205^{*}$ \\
BDIVER & & & 1 & -0.061 & 0.064 & $-0.233^{* *}$ & 0.062 \\
BMEET & & & & 1 & 0.087 & $0.230^{* *}$ & -0.129 \\
CEODUAL & & & & & 1 & $-0.237^{* *}$ & $0.216^{*}$ \\
ACSIZE & & & & & & 1 & $-0.198^{*}$ \\
AUDTYP & & & & & & & 1 \\
\hline
\end{tabular}

Note: Audit Report Lag (ARL), Board Size (BSIZE), Board Diversity (BDIVER), Board Meeting (BMEET), Chief Executive Officer Duality (CEODUAL), Audit Committee Size (ACSIZE), Auditor Type (AUDTYP).

*. Correlation is significant at the 0.05 level (2-tailed)

${ }^{* *}$. Correlation is significant at the 0.01 level (2-tailed)

\section{Multiple Regression}

Table 7 demonstrates the regression results of the independent variables and dependent variable, audit report lag. The $\mathrm{R}^{2}$ value of 0.123 from the table below revealed that board size (BSIZE), board diversity (BDIVER), board meeting (BMEET), CEO duality (CEODUAL), audit committee size (ACSIZE) and auditor type (AUDTYP) can explain 12.3\% of variations in the dependent variable, audit report lag (ARL). The remaining $87.7 \%$ of the audit report lag is explained by other non-corporate governance factors that are not included in the model. This result is almost the same as in previous studies by Nelson and Shukeri (2011); Alsmady (2018) and Bakare et al. (2018) who reported a value of R2 12.9\%, 13.0\% and 18.2\% respectively. The value of R2 adjusted decreasing to 0.083 indicated that the variables tested in this study have no significant relationship between audit report lag.

Table 7: Regression Results of Independent Variables and Audit Report Lag

\begin{tabular}{lccc}
\hline \multicolumn{1}{c}{ Variables } & Beta & T & Sig \\
\hline Constant & 4.733 & 8.832 & 0.000 \\
BSIZE & -0.084 & -2.298 & 0.023 \\
BDIVER & 0.119 & 2.185 & 0.031 \\
BMEET & -0.014 & -0.568 & 0.571 \\
CEODUAL & -0.055 & -0.514 & 0.608 \\
ACSIZE & -0.695 & -1.127 & 0.262 \\
AUDTYP & -0.241 & -2.574 & 0.011 \\
\hline $\mathrm{N}$ & 138 & & \\
$\mathrm{R}^{2}$ & 0.123 & & \\
Adjusted $\mathrm{R}^{2}$ & 0.083 & & \\
$\mathrm{~F}$ & 3.054 & & \\
Sig. & 0.008 & & \\
\hline Note: Dependent variable: Audit Report Lag (ARL) &
\end{tabular}


Board Size (BSIZE), Board Diversity (BDIVER), Board Meeting (BMEET), Chief Executive Officer Duality (CEODUAL), Audit Committee Size (ACSIZE), Auditor Type (AUDTYP).

The $\mathrm{F}$ value and p-value in Table 7 explain the general statistical significance of the model in this study. The value of $\mathrm{F}$ critical from $\mathrm{F}$ Distribution table when the numerator degree of freedom is 6 and the denominator degree of freedom is 131 is $2.10\left(\mathrm{~F}_{.05}=2.10\right)$. Meanwhile, the value of $\mathrm{F}$ observed is 3.05. This indicated that the value of $\mathrm{F}$ observed is more than value of $\mathrm{F}$ critical, showing a significant linear relationship between the dependent variable and all independent variables in this study. Furthermore, the $\mathrm{p}$-value was $0.008(\mathrm{p}<.05)$ concluding that there is evidence that at least one independent variable affects the dependent variable, audit report lag. Thus, the overall model is statistically significant and fit.

\section{Board Size and Audit Report Lag}

The results in Table 7 show that there is a significant negative relationship between board size and audit report lag, where p-value is 0.023 $(\mathrm{p}<.05)$. It indicates that ARL is believed to be decreased by 0.084 when one additional unit increased in BSIZE. This result is aligned with previous studies by Hassan (2016); Ahmed and Che-Ahmad (2016) who documented a significant relationship between board size and audit report lag. The studies found that in the complex nature of business activities, larger boards can be more effective by providing better monitoring mechanisms. Thus, a large board size could reduce audit report lag in the sample companies. Even though there is no specific number of directors that should be on the board as proposed by Bursa Malaysia and MCCG, it is always argued whether a smaller or larger board is more effective. Rodríguez-Fernández (2015) recommended that a size of between 5 and 15 members could be the optimal size for a board. A large board size represents the resources of the companies in terms of knowledge, ideas and experience that can enhance decision making process. A previous study conducted by Al Daoud et al. (2015) reported a significant relationship between board size and audit report lag, however the study found that a large board size increased audit report lag in their sample companies. Similar to the study by Ilaboya and Christian (2014) who found that a larger board size will increase audit report 
lag, but the result was not significant. The result in this study is not aligned with the Agency Theory that stated that larger boards size are unexpected to be effective, less meaningful and discourage board performance due to the free riding problem. Therefore, $\mathrm{H}_{1}$ is accepted..

\section{Board Diversity and Audit Report Lag}

The results of the study demonstrate that there is a positive significant relationship between board diversity and audit report lag, where the p-value is $0.031(\mathrm{p}<.05)$. It indicates that ARL is presumed to be increased by 0.119 when one additional unit increases in BDIVER. This result is aligned with a recent study conducted by Alsmady (2018) who reported a significant relationship between board diversity and audit report lag. The study found that the existence of females in the board of directors will prolong audit report lag. This is because the Jordanian culture does not prefer females on the board. Furthermore, board diversity enables more diverse opinions and critical questions that will prolong the decision-making process (Hassan, Marimuthu, \& Johl, 2015). Even though MCCG proposed that companies have gender diversity in the board of directors, this study found that the existence of females in the board of directors shows a negative influence with audit report lag. This might be due to the higher risk of conflicts arising which contributes to a longer decision-making process. On the other hand, results from previous studies by Ahmed and Che-Ahmad (2016); Khuong et al. (2017) reported a significant relationship between board diversity and audit report lag. However, the studies show that the increase of females in the board of directors contributes to shorten audit report lag. Thus, the studies supported the argument that gender diversity will have behavioural effects, which lead to better outcomes of a company's performance and could affect audit report lag. In contrast, Singh and Sultana (2011) reported no significant relationship between board diversity and audit report lag, but the existence of females in the board of directors lessened audit report lag in their sample. It has been found that females tend to take less risks and attend not to break rules, thus they will ensure to provide timely financial reporting. Therefore, $\mathrm{H}_{2}$ is accepted. 


\section{Board Meeting and Audit Report Lag}

Results in Table 7 shows that there is no significant negative relationship between board meeting and audit report lag, where p-value is $0.571(\mathrm{p}>.05)$. However, it indicates that ARL is believed to be decreased by 0.014 when one additional unit increase in BMEET. This finding is on par with that reported by Li (2014) who found no significant relationship between board meeting and timeliness of financial reporting. However, result in the study indicated an increase in the frequency of board meeting would produce timely financial reporting. Board meeting portray the board activities to enhance monitoring mechanisms. It has been shown that effective board of directors are linked with more frequent board meetings as it help the board to improve monitoring activities over the process of financial reporting (Greco, 2011). This finding is also aligned with Singh and Sultana (2011) who found no significant relationship between board meeting and audit report lag. However, the result indicated that an increase in board meetings would prolong audit report lag. This might be due to more conflicts arising during board meetings. In contrast, previous studies conducted by Al Daoud et al. (2015) and Ahmed and Che-Ahmad (2016) reported a significant relationship between board meeting and audit report lag. Further, the results indicate that more frequent board meetings would reduce audit report lag. Therefore, $\mathrm{H}_{3}$ is rejected.

\section{Chief Executive Officer Duality and Audit Report Lag}

The results of the study demonstrated that there is no significant negative relationship between chief executive officer duality and audit report lag, where $\mathrm{p}$-value is $0.608(\mathrm{p}>.05)$. However, it indicates that ARL is presumed to be decreased by 0.055 when one additional unit increase in CEODUAL. This findings is on par with Hassan (2016) who found no significant relationship between CEO duality and audit report lag. Further, the result indicated that the separation of the roles of chairman of the board and CEO is more likely to prolong audit report lag. Even though the MCCG recommends companies to have two different individuals that holding the position of chairman of board so as to ensure proper monitoring functions by the top management but the result in this study shows that separation of this roles will only lengthen audit report lag. Separation of the roles of the chairman and CEO will reduce the risk of audit failure; hence an 
extensive audit will be conducted to ensure the quality of the audit (Hassan, 2016). The result does not align with the Agency Theory that states that the existence of CEO duality significantly lessens board effectiveness in protecting various stakeholders' interests. In contrast, previous studies conducted by Al Daoud et al. (2015) and Alfraih (2016) who reported a significant relationship between CEO duality and audit report lag. Further, the studies also found that the separation of the roles of the chairman and CEO reduces audit report lag. Therefore, $\mathrm{H}_{4}$ is rejected.

\section{Audit Committee Size and Audit Report Lag}

Results in Table 7 show that there is no significant negative relationship between audit committee size and audit report lag, where p-value is 0.262 ( $p$ >.05). However, it indicates that ARL is believed to be decreased by 0.695 when one additional unit increase in ACSIZE. This finding is aligned with previous studies by Ahmed and Che-Ahmad (2016) and Cunha et al. (2016) that documented no significant relationship between audit committee size and audit report lag. However, the results further indicate that large audit committees would reduce audit report lag. Audit committee will be monitoring financial reporting practices and respond to the emergence of problems in the company. It has been reported from a recent study that audit committee size must have an adequate number of committee members to ensure the effectiveness in performing their roles (Oussii \& Taktak, 2018). An effective audit committee will enhance internal controls of a company thus, the time taken by the external auditors to complete their audit work would be reduced. In contrast, a recent study conducted by Lirungan and Harindahyani (2018) reported a significant relationship between audit committee size and audit report lag. Further, the result also indicates that an increase in the number of audit committee size will reduce audit report lag. Therefore, $\mathrm{H}_{5}$ is rejected.

\section{Auditor Type and Audit Report Lag}

The results of this study demonstrate that there is a significant negative relationship between auditor type and audit report lag, where p-value is $0.011(\mathrm{p}<.05)$. It indicates that ARL is presumed to be decreased by 0.241 when one additional unit increase in AUDTYP. This result is aligned with recent previous study by Lirungan and Harindahyani (2018) who reported 
significant relationship between auditor type and audit report lag. The study found that Big Four or large audit firms are more likely to complete their audit work timely compared to small audit firms. Further, other researchers also supported this argument by documenting a significant relationship in their study between auditor type and audit report lag (Cunha et al., 2016; Shukeri \& Islam, 2012). The effectiveness of large audit firms in performing their audit work could enable them to accelerate the audit process and produce timely financial reporting. As discussed earlier in the literature review, the type of external auditor could affect audit report lag especially for large audit firms. This is because large audit firms have better resources and technologies compared to small audit firms. Large audit firms in this study refer to the Big Four audit firms (Deloitte, PWC, E\&Y and KPMG). The advantages of having better experienced staff and well-programmed audit procedures, could enable the Big Four firms to complete their audit work on time. Thus, it shortens audit report lag. However this result contradicts with the study conducted by Afify (2009), which found no significant relationship and that companies audited by the Big Four will prolong audit report lag. Therefore, $\mathrm{H}_{6}$ is accepted.

\section{CONCLUSION AND RECOMMENDATION}

The issue of timely financial reporting is not an overwhelming issue. It has been debated and increasingly addressed by accounting standards setting entities all over the globe because the delay in financial reporting is most likely to boost information asymmetry and uncertainty in investment decisions. Timely financial reporting is one of the measurements of financial reporting quality. As users of financial information usually demand for complete, transparent, accurate, reliable and timely information, it is important to examine the factors contributing to the audit report lag. The current scenario in Malaysia is it is always portrayed as unable to submit their audited annual report within the timeframe as required by Bursa Malaysia (Hashim, 2017). Thus, this study examined the determinants of audit report lag from a corporate governance perspective in listed companies in the construction industry in Malaysia.

Notably, corporate governance provides a framework of control mechanisms that help a company in fulfil its goals, while preventing 
undesirable conflicts (Al Daoud et al., 2015; Azubike \& Aggreh, 2014). According to the Agency Theory, the distinction of ownership and control in firm, may result in conflicts of interest between owners and managers (Dawar, 2014). In addition, the Theory proposed that corporate governance has the direct obligation in promoting financial reporting quality and oversight processes which affect audit report lag. Hence, effective corporate governance should lessen business risks and enhance internal controls to shorten audit report lag. The construction industry in Malaysia, is one of the most challenging and dynamic industries and the role of corporate governance is to act as a control and oversight mechanism which may help construction companies to lessen their risks and provide timely financial information to users.

The results from this study will provide recent empirical evidence relating to audit report lag of 138 construction companies listed on Bursa Malaysia from 2015 to 2017. The results in this study demonstrated that corporate governance does have an impact on audit report lag. The Agency Theory has served as the theoretical framework in this study to see the relationship between corporate governance and audit report lag. Hence, there are several corporate governance attributes such as board size and board diversity that have impacted audit report lag. In addition, auditor type also affects audit report lag which suggests that the Big Four have better timeliness in financial reporting. While board meetings, CEO duality and audit committee size had no significant effect on audit report lag in this sample companies.

The descriptive statistics demonstrated that the average audit report lag in the listed companies is 99 days. The maximum audit report lag for this sample companies is 121 days and the minimum is 55 days. The results demonstrate that the companies complied with the Bursa Malaysia listing requirements which required all companies to publish their annual reports within 4 months after the financial year end except for one company that exceeded the 4 months period.

Multiple regressions were conducted to meet the objectives of this study. The objective of this study was to examine the relationship between board size, board diversity, board meeting, CEO duality, audit committee size, auditor type with audit report lag listed companies in the construction 
industry in Malaysia. The result from the multiple regression demonstrated that board size, board diversity and auditor type have a significant relationship with audit report lag. The study found that a large board size and large audit firms reduce audit report lag. However, the existence females in board of directors will prolong audit report lag. Further, the study found that there is no relationship between board meeting, CEO duality and audit committee size with audit report lag. However, the study found that more frequent board meetings, existence of CEO duality and large audit committee size reduces audit report lag.

\section{Limitations of the Study}

Firstly, this research is only focused on one industry which is the construction industry. The characteristics of corporate governance structure on sample companies in construction industry are deemed to be similar. While other industries might have a different setup for corporate governance structure to accommodate with the nature and complexity of their business. Thus, that may result in different findings.

Secondly, this research focussed on the effects of five corporate governance characteristics and auditor type on audit report lag. While there are many other corporate governance attributes, auditor attributes and may also include company attributes to justify the dependent variable, audit report lag.

Thirdly, this research covered the period 2015 to 2017 only, that is after the new requirement by Bursa Malaysia regarding the timeframe for the publication of the annual report. A clear picture of the differences on the effect of corporate governance and auditor type before and after the new requirement may have not been fully observed.

\section{Recommendation of Future Study}

Firstly, future researchers might consider to not only focus on one industry. Public listed companies from other industries should be used to represent the total population of public listed companies in Malaysia. This is due to the fact that the different nature of business may have a different corporate governance setting depending on their needs. 
Secondly, future researchers should expand the model used in this study so as to strengthen the explanation of audit report lag. It is suggested to study on other variables such as company performance, audit committee meetings and audit fees that may improve the predictive model of audit report lag. Other than that, future studies may also consider government ownership and political connections which could potentially influence audit report lag.

Thirdly, future researchers might consider conducting an analysis for a longer period such as five years, starting from 2013 which is before the implementation of new Bursa Malaysia requirement. This would provide a clear picture of trends in audit report lag of public listed companies in Malaysia. Furthermore, it would enhance the accuracy of the results since the new requirement from Bursa Malaysia could affect audit report lag in Malaysian public listed companies.

\section{REFERENCES}

Abdul Rahman, H., Wang, C., \& Sheik Mohamad, F. (2015). Implemention of risk management in the Malaysian construction industry. Journal of Construction Engineering, 2015, 1-6.

Abdullah, S. N. (2006). Directors' remuneration, firm's performance and corporate governance in Malaysia among distressed companies. The International Journal of Business in Society, 6(2), 162-174.

Abernathy, J. L., Barnes, M., Stefaniak, C., \& Weisbarth, A. (2016). An international perspective on audit report lag: A synthesis of the literature and opportunities for future research. International Journal of Auditing, $21(1), 100-127$.

Abernathy, J. L., Beyer, B., Masli, A., \& Stefaniak, C. (2014). The association between characteristics of audit committee accounting experts, audit committee chairs, and financial reporting timeliness. Advances in Accounting, 30(2), 283-297. 
Afify, H. A. E. (2009). Determinants of audit report lag: Does implementing corporate governance have any impact? Empirical evidence from Egypt. Journal of Applied Accounting Research, 10(1), 56-86.

Agyei-Mensah, B. K. (2018). Impact of corporate governance attributes and financial reporting Lag on corporate financial performance. African Journal of Economic and Management Studies, 9(3), 349-366.

Ahmed, M. I., \& Che-Ahmad, A. (2016). Effects of corporate governance characteristics on audit report lags. International Journal of Economics and Financial Issues, 6(S7), 159-164.

Akingunola, R. O., Soyemi, K. A., \& Okunuga, R. (2018). Client attributes and the audit report lag in Nigeria. Market Forces, 13(1), 30-41.

Al Daoud, K. A., Ku Ismail, K. N. I., \& Lode, N. A. (2014). The timeliness of financial reporting among Jordanian companies: Do company and board characteristics, and audit opinion matter? Asian Social Science, 10(13), 191-201.

Al Daoud, K. A., Ku Ismail, K. N. I., \& Lode, N. A. (2015). The impact of internal corporate governance on the timeliness of financial reports of Jordanian firms: Evidence using audit and management report lags. Mediterranean Journal of Social Sciences, 6(1), 430-442.

Alfraih, M. M. (2016). Corporate governance mechanisms and audit delay in a joint audit regulation. Journal of Financial Regulation and Compliance, 24(3), 292-316.

Alnasser, S. (2012). What has changed? The development of corporate governance in Malaysia. The Journal of Risk Finance, 13(3), 269-276.

Alqatamin, R. M. (2018). Audit committee effectiveness and company performance: Evidence from Jordan. Accounting and Finance Research, $7(2), 48-60$.

Alsmady, A. A. (2018). The effect of board of directors' characteristics and ownership type on the timeliness of financial reports. International Journal of Business and Management, 13(6), 276-287. 
Apadore, K., \& Noor, M. M. (2013). Determinants of audit report lag and corporate governance in Malaysia. Business and Management, 8(15), $151-163$.

Appah, E., \& Emeh, Y. (2013). Corporate governance structure and timeliness of financial reports of quoted firms in Nigeria. European Journal of Business and Management, 5(32), 34-45.

Azubike, J. U. B., \& Aggreh, M. (2014). Corporate governance and audit delay in Nigerian quoted companies. European Journal of Accounting and Finance Research, 2(10), 22-33.

Baatwah, S. R., Salleh, Z., \& Ahmad, N. (2015). CEO characteristics and audit report timeliness: Do CEO tenure and financial expertise matter? International Journal for Researcher Development, 7(1), 63-83.

Badawy, H., \& Aa, E. W. (2018). The main audit related determinants of ARL in an emerging economy: The case of Egypt. International Journal of Accounting Research, 6(2), 184.

Bakare, O. U., Taofiq, A., \& Jimoh, J. A. (2018). Effect of board characteristics on timeliness of financial reporting of listed insurance firms in Nigeria. Online Journal of Arts, Management and Social Sciences, 3(1), 126-136.

Basuony, M. A. K., Mohamed, E. K. A., Hussain, M. M., \& Marie, O. K. (2016). Board characteristics, ownership structure and audit report lag in the Middle East. International Journal of Corporate Governance, $7(2), 180-205$.

Boshkoska, M. (2014). The agency problem: Measures for its overcoming. International Journal of Business and Management, 10(1), 204-209.

Bouckova, M. (2015). Management accounting and agency theory. Economics and Finance, 25(15), 5-13.

Bursa Malaysia. (2015). Main market listing requirements. Retrieved October 16, 2018, from http://customer.bursamalaysia.com:8080/ MainLR/Pa ges/FAQ 9.40.aspx 
Cunha, P. R. da, Pletsch, C. S., \& Silva, A. da. (2016). Relation between the characteristics of the company, the audit committee and the independent auditor and the publication deadline of the financial statements. Revista de Educação e Pesquisa Em Contabilidade, 9(4), 402-416.

Dawar, V. (2014). Agency theory, capital structure and firm performance: Some Indian evidence. Managerial Finance, 40(12), 1190-1206.

Ezat, A., \& El-masry, A. (2007). The impact of corporate governance on the timeliness of corporate internet reporting by Egyptian listed companies. Journal of Managerial Finance, 34(12), 848-867.

Gamayuni, R. R., Karlina, \& Lindrianasari. (2018). Determinant analysis of audit report lag in regional governments in Indonesia. International Journal of Scientific \& Technology Research, 7(4), 105-110.

Greco, G. (2011). Determinants of board and audit committee meeting frequency. Managerial Auditing Journal, 26(3), 208-229.

Habib, A. (2013). A meta analysis of the determinants of modified audit opinion decisions. Managerial Auditing Journal, 28(3), 184-216.

Habib, A., \& Bhuiyan, M. B. U. (2011). Audit firm industry specialization and the audit report lag. Journal of International Accounting, Auditing and Taxation, 20(1), 32-44.

Hashim, U. J. (2017). Does ownership characteristics have any impact on audit report lag? Evidence of Malaysian listed companies. World Applied Sciences Journal, 35(9), 1826-1838.

Hashim, U. J., \& Abdul Rahman, R. (2011). Audit report lag and the effectiveness of audit committee among Malaysian listed companies. International Bulletin of Business Administration, 10(10), 50-61.

Hashim, U. J., \& Abdul Rahman, R. (2011, November). Board independence, board diligence, board expertise and impact on audit report lag in Malaysian market. In Finance and Corporate Governance Conference. 
Hassan, R., Marimuthu, M., \& Johl, S. K. (2015). Diversity, corporate governance and implication on firm financial performance. Global Business \& Management Research, 7(2), 28-36.

Hassan, Y. M. (2016). Determinants of audit report lag: Evidence from Palestine. Journal of Accounting in Emerging Economies, 6(1), 13-32.

Ilaboya, O. J., \& Christian, I. (2014). Corporate governance and audit report lag in Nigeria. International Journal of Humanities and Social Science, 4(13), 172-180.

Jensen, M. C., \& Meckling, W. H. (1976). Theory of the firm: Managerial behaviour, agency cost and ownership structure. Journal of Financial Economic, 3, 305-360.

Khuong, N. V., Thi, N., \& Vy, X. (2017). CEO characteristics and timeliness of financial reporting of Vietnamese listed companies. Journal of Science, Economic and Business, 33(5), 100-107.

Lee, H. Y., \& Jahng, G. J. (2008). Determinants of audit report lag: Evidence from Korea - An examination of auditor-related factors. Journal of Applied Business Research, 24(2), 27-44.

Li, Y. (2014). The influence of corporation governance structure on internal control audit report lag: Evidence from China. Accounting \& Taxation, 6(2), 101-115.

Lirungan, D., \& Harindahyani, S. (2018). The effect of corporate governance on audit report timeliness in Indonesia. Jurnal Akuntansi Bisnis, 16(2), 80-94.

Mahmoud Ezat, A. N. (2015). The impact of audit- related factors on audit report lag for the Egyptian listed non-financial companies. Journal of the Faculty of Commerce for Scientiic Research, 10(1), 1-45.

Malaysian Accounting Standard Board. (2015). Financial report filing requirements around the world, 1-6. Retrieved from https://www. ifrs.org/-/media/feature/around-the-world/filing-profiles/malaysia-8june-2015.pdf 
Mhetre, K., Konnur, B. A., \& Landage, A. B. (2016). Risk management in construction industry. International Journal of Engineering Research, 5(Special 1), 153-155.

Mohamad-Nor, M. N., Shafie, R., \& Wan-Hussin, W. N. (2010). Corporate governance and audit report lag. Asian Academy of Management Journal of Accounting and Finance, 6(2), 57-84.

Nelson, S. P., \& Shukeri, S. N. (2011). Corporate governance and audit report timeliness: Evidence from Malaysia. Research in Accounting in Emerging Economies, 11(1), 109-127.

Oussii, A. A., \& Taktak, N. B. (2018). Audit committee effectiveness and financial reporting timeliness: The case of Tunisian listed companies. African Journal of Economic and Management Studies, 9(1), 34-55.

Pizzini, M., Lin, S., \& Ziegenfuss, D. E. (2012). The impact of internal audit function quality and contribution on audit delays. Auditing: A Journal of Practice \& Theory, 34(1), 25-58.

Puasa, S., Salleh, M. F. M., \& Ahmad, A. (2014). Audit committee and timeliness of financial reporting: Malaysian public listed companies. Middle-East Journal of Scientific Research, 22(2), 162-175.

Queirós, A., Faria, D., \& Almeida, F. (2017). Strengths and limitations of qualitative and quantitative research methods. European Journal of Education Studies, 3(9), 369-386.

Rodríguez-Fernández, M. (2015). Company financial performance: Does board size matter? Case of the EUROSTOXX50 index. Cuadernos de Gestion, 15(2), 15-38.

Rusmin, R., \& Evans, J. (2017). Audit quality and audit report lag: Case of Indonesian listed companies. Asian Review of Accounting, 25(2), 191-210.

Sakka, I. F., \& Jarboui, A. (2016). Audit reports timeliness: Empirical evidence from Tunisia. Cogent Business and Management, 3(1), 1-13. 
Salehi, M., Bayaz, M. L. D., \& Naemi, M. (2018). The effect of CEO tenure and specialization on timely audit reports of Iranian listed companies. Management Decision, 56(2), 311-328.

Salleh, Z., Baatwah, S. R., \& Ahmad, N. (2017). Audit committee financial expertise and audit report lag: Malaysia further insight. Asian Journal of Accounting and Governance, 8, 137-150.

Sari, B. G., Lúcio, A. D., Santana, C. S., Krysczun, D. K., Tischler, A. L., \& Drebes, L. (2017). Sample size for estimation of the Pearson correlation coefficient in cherry tomato tests. Ciência Rural, 47(10).

Shukeri, S. N., \& Islam, M. A. (2012). The determinants of audit timeliness: Evidence from Malaysia. Journal of Applied Sciences Research, 8(7), 3314-3322.

Siang, L. C., \& Ali, A. S. (2012). Implementation of risk management in the Malaysian construction industry. Journal of Surveying, Construction \& Property, 3(1), 15.

Singh, H., \& Sultana, N. (2011). Board of director characteristics and audit report lag: Australian evidence. Corporate Board: Role, Duties and Composition, 7(3), 38-51.

The Sun Daily. (2013). From 2016, listed companies have 4 months to issue annual reports. Retrieved October 16, 2018, from http://www. thesundaily.my/news/916581

Wan Hussin, W. N., Bamahros, H. M., \& Shukeri, S. N. (2018). Lead engagement partner workload, partner-client tenure and audit reporting lag: Evidence from Malaysia. Managerial Auditing Journal, 33(3), 246-266. 